\title{
The Threatened History and Collective Memory of the Cultural Revolution's Lost Generation
}

\section{Michel Bonnin}

\section{Q OpenEdition}

\section{Journals}

Édition électronique

URL : http://journals.openedition.org/chinaperspectives/2573

DOI : $10.4000 /$ chinaperspectives. 2573

ISSN : 1996-4617

Éditeur

Centre d'étude français sur la Chine contemporaine

\section{Édition imprimée}

Date de publication : 15 décembre 2007

ISSN : 2070-3449

Référence électronique

Michel Bonnin, «The Threatened History and Collective Memory of the Cultural Revolution's Lost Generation », China Perspectives [En ligne], 2007/4 | 2007, mis en ligne le 30 décembre 2010, consulté le 10 décembre 2020. URL : http://journals.openedition.org/chinaperspectives/2573 ; DOI : https:// doi.org/10.4000/chinaperspectives. 2573 
$[7$

The Threatened History

\section{and Collective Memory of}

the Cultural Revolution's

Lost Generation

MICHEL BONNIN

Since the Communist Party of China published its brief official version of the Cultural Revolution in 1981, few works on the history of that period have been approved for publication, even if they have kept strictly to the orthodox line. Still, some research work and eye-witness accounts by Chinese people outside the official apparatus have appeared, mostly in Hong Kong and Taiwan but also on the mainland. In spite of official attempts to bury the memory of that time, and against the grain of unreliable nostalgic recollections of some of their contemporaries, some former Red Guards and educated youth have managed, against all the odds, to put together an authentic and critically aware "people's" memory. These scattered islands of memory of China's "lost generation" are under constant threat of submersion, but they are worth our attention, not only because they are essential for the future of China but also because the Cultural Revolution was an event of global significance.

$\mathrm{T}$ The People's Republic of China (PRC) is a country where one party, the Communist Party, not only lays claim to a monopoly on the exercise of power but also to the production and distribution of ideology. This includes the narration and interpretation of History, and consequently the forging of the collective memory. In the Maoist epoch, the interpretation of History was closely linked to many political struggles. To give two examples from the period that concerns us here, the Cultural Revolution started with a debate over a Ming dynasty official, Hai Rui, and a few years later, Mao launched his Movement to Criticise Lin Biao and Confucius. The latter amalgamation of a Red Army leader who had recently died after an alleged plot, and the ancient sage who had been a pillar of the imperial order for about two millennia, perplexed not only foreign observers but also the Chinese themselves.

\section{History exclusively in the service of politics}

Although the Chinese Communist Party (CCP) has revealed very little about its own history, preferring to leave it locked up in the mysterious "Central Committee archives," Mao had felt as early as the Yan'an period the need to assert his supreme political control over the "correct" version of the Party's history. This was one of the objectives of the Rectification Movement of 1942, which found expression in 1945 in the "Resolution concerning several historical questions." This text not only institutionalised and legitimised the cult of Mao within the Party but it also set the pattern for the Party's way of dealing with History. ${ }^{(1)}$ In this approach,

1. See especially, He Fang, Dangshi biji - cong Zunyi huiyi dao Yan'an zhengfeng (Notes on the history of the party - from the Zunyi conference to the Yenan rectification movement), Hong Kong, Liwen chubanshe, 2005, pp. 633-702. 
truthfulness gives way to political expediency, which is defined in its turn by the leadership's response to the current situation. In addition, stereotypical versions of "good" and "bad" replace historical complexity; setbacks and mistakes are not mentioned or are played down, and successes are greeted with triumphant exaggeration. In short, History is simply pressed into the service of political interests.

Following the launch of Deng Xiaoping's reforms in 1978, the CCP gave up its utopian goal of the ideological transformation of human nature, but it continued to use ideology as a means of legitimising its hold on power and preventing the emergence of new ideas that might threaten it. Since that turning point, the Party has kept up its traditional production of official history, which includes recent history, as was clearly demonstrated in June 1981 when the 6th plenary session of the 11th Central Committee adopted the "Resolution on several questions concerning the history of our Party since the foundation of the People's Republic of China." The very title of this resolution shows that it should be seen as a continuation of the 1945 version; the same characteristics that we have seen defining that earlier "historical resolution" are to be found here as well. The difference is that the first resolution established the cult of Mao, whereas the later one tried to protect the Great Helmsman by minimising his "mistakes" and laying the blame for nearly all the crimes of the Cultural Revolution on Lin Biao and the Gang of Four. With regard to collective memory, the Party has continued its efforts to mould it according to its will, whether by printed or audiovisual propaganda, school textbooks, public ceremonies, or any other means. For example, since 1997 lists have been drawn up containing several hundred geographical sites designated as "bases for patriotic education." Students, cadres, model workers, and the population at large are all encouraged to partake in "red tourism" by visiting these sites and becoming familiar with the lofty deeds of the heroes of the Chinese nation, among whom the Communist revolutionaries are given pride of place. ${ }^{(2)}$

On the other hand, the official attitude with regard to historical research on the post-1949 period has generally been to promote forgetfulness and to forbid serious academic investigation. One of these "forbidden areas" has been, and still is, the "Cultural Revolution," defined officially as the 10 years between 1966 and 1976. In the late 1970s and the early 1980s, negative accounts of the period were encouraged on condition that they were aimed against the Gang of Four and not against Mao. But nowadays further study of that decade has not been allowed, because it might endanger Mao's image and legitimacy, and consequently those of the Party, which has no other guiding model to replace him. However, we should note that some extremely heterodox views on the Cultural Revolution were able to find an outlet during the very short period between the end of 1978 and the autumn of 1979, when the publication of parallel journals (minban kanwu) was tolerated. At that time, it was a matter of using the "democracy wall" movement to support Deng Xiaoping's legitimacy against the Party conservatives, but as soon as the new leader had achieved his goal the movement was suppressed. ${ }^{(3)}$ The two most significant contributions were written by former Red Guards and educated youth from Guangzhou. The first of these was "A short analysis of the Cultural Revolution" by Liu Guokai, the first draft of which went back to 1971. It appeared in a special issue of the parallel journal, The Voice of the People (Renmin zhi sheng), founded by Liu in December 1980. ${ }^{(4)}$ This was probably the first history of the "three years of the Cultural Revolution" to be written, and the first to insist that the movement gave China's youth a small taste of the freedoms theoretically guaranteed by the Constitution. It also welcomed the "awakened consciousness" to which the movement gave rise in quite a number of former Red Guards. The other text was penned by Wang Xizhe, who was a member of the Li Yizhe group, well known for putting up a wall newspaper in Guangzhou in 1973, and a democracy movement activist in that city in the late 1970s. Entitled "Mao Zedong and the Great Cultural Revolution," it asserts both that Mao was not really an enemy of the bureaucracy and that a spin-off of the Cultural Revolution, not intended by the Great Helmsman, was the production of a "reflective generation" capable of taking a critical stance towards the official ideology. ${ }^{(5)}$ Even if this idea is suggested throughout Liu's article, it is Wang's that provides the first formulation of the term "Cultural Revolution by the people," to which we will return.

\section{The history of an epoch and of a generation}

Despite the official silence that has been continually imposed since that time, there exists nowadays a wide range of books and articles in Chinese dealing with the Cultural Rev-

2. Information on this tourist programme can be found on one of the websites dealing with "official memory": www.xibaipo.com

3. See Victor Sidane, Le Printemps de Pékin, Gallimard, collection Archives, 1980.

4. At that point, most of the parallel journals were forced to close and those that continued to appear were no longer distributed publicly. In 1981, even private distribution was forbidden, and all the journals had to close.

5. Wang Xizhe, "Mao Zedong yu wenhua geming," Shidai, Hong Kong, February 1981. 
olution. They cover the spectrum from the officially approved to the dissident, but a large number of them are not published on the mainland, and are therefore not easily accessible by the citizens of the PRC, except by those living in Hong Kong and Macao.

\section{Official, semi-official, or officially tolerated histories}

It could well be said that the only official history of the $\mathrm{Cul}$ tural Revolution, the one always quoted officially, is set out in the passage dealing with that historical episode in the "Resolution" of 1981. During periods of relative "liberalisation," however, the CCP has tolerated the publication of semi-official histories. Out of the three main works that fall under this category, and are briefly introduced in Wang Youqin's article in this issue, ${ }^{(6)}$ two (one by Gao Gao and Yan Jiaqi, and the other by Wang Nianyi) were published during the relatively liberal period before the turning point on 4 June 1989. The third work, by Jin Chunming, was the only one to appear after that point. ${ }^{(7)}$ During the following year Jin also published, jointly with Xi Yan, a Short history of the "Great Cultural Revolution", which was intended to serve as a kind of textbook on the topic. ${ }^{(8)}$ In 1998, a group of experts on Party documents and archives also received permission to produce a completely orthodox history, which came out the following year. This has the advantage of providing a semi-official account of the major events of the period between 1966 and the famous 3rd plenary session of the 11th Central Committee at the end of 1978. This plenary session in fact represented a more decisive historical turning point than the arrest of the Gang of Four, even though the one could certainly not have happened without the other. Moreover, this group's identification of a 12-year historical period deserves to be considered more satisfactory than the usual "10 years of the Cultural Revolution." However, their work has one serious flaw; it does not reference its sources, whereas the other official works at least provide some reference material whenever it is not considered to be "secret." (9)

It is obvious that all these writers have deliberately formulated their analyses in conformity with official views and that, as Wang Youqin observes, their work suffers from being limited to official documents and sources, and to certain Red Guard publications. Nonetheless, there are different gradations within the "official" quality of their separate contributions. For example, as Wang Nianyi says (op. cit. p. 559), although his book received official approval from the
Propaganda Department of the Central Committee, it was the product of personal research, and it clearly expresses his desire to struggle against the consignment of those painful historical events to oblivion (p. 556). In his 1988 postscript he also explains that, being unconvinced by the official version of a particular matter, he opted to leave it out completely (p. 558). And in his postscript to the second edition of 1994, he even acknowledges his work's limitations, particularly with regard to his omission of the large number of the victims in 1966 (p. 558). Of course, these attempts at selfcriticism and distancing himself from the official line do not undermine Wang Youqin's generally justified criticism.

To those works that seek to provide a comprehensive view of the period we should add another kind of semi-official publication, namely the collections of contributions from various authors focused on particular issues. These are generally more analytical than factual and documentary. The two most important of such works are without doubt "An assessment 10 years later: collected historical essays on the $\mathrm{Cul}$ tural Revolution," ${ }^{(10)}$ published in 1987, and "A return to the Cultural Revolution - analysis and reflections on the 10 years of the Chinese Cultural Revolution," (II) published in 2000. These two works, like that of Xi Yan and Jin Chunming, were published by official outlets for works related to the history of the Party, and this gives them a semi-official character, underlined further by the fact that the main authors are professional Party historians. However, it should be noted that the second of the two collections covers a wider intellectual range. Although it opens with contributions from some of the most conservative Party intellectuals, such as $\mathrm{Hu}$ Qiaomu and $\mathrm{Hu}$ Sheng, there is also a contribution from Yin Hongbiao, a historian who lectures in international relations at Peking University, and who for several

6. Gao Gao \& Yan Jiaqi, Wenhua da geming shinian shi (History of the ten years of the Great Cultural Revolution), Tianjin renmin chubanshe, 1986; Wang Nianyi, Da dongluan de niandai (The time of the great chaos), Henan renmin chubanshe, 1988 (republished in 1992 and 2004); Jin Chunming, Wenhua geming shigao (An outline history of the Cultural Revolution), Sichuan renmin chubanshe, 1995

7. It should be noted, moreover, that the official in charge of the Sichuan People's Publications who published it was later reprimanded by the authorities in charge of propaganda.

8. Xi Yan \& Jin Chunming, Wenhua da deming jianshi (Brief history of the Cultural Revolu tion), Zhonggong dangshi chubanshe, 1996.

9. Yang Shengqun \& Tian Songnian (eds), Gongheguo zhongda juece de lailongqumo (1966-1978) (The circumstances pertaining to the major political decisions in the PRC 1966-1978), Jiangsu renmin chubanshe, 1999.

10. Tan Zongji et al., Shinian hou de pingshuo - "wenhua da geming" shilunji, Zhonggong dangshi ziliao chubanshe, 1987.

11. Zhang Hua et al., Huishou "wenge" - Zhongguo shinian "wenge" fenxi yu fansi (2 vols.), Zhonggong danshi chubanshe, 200. 
The historian Liu Xiaomeng at the time he was sent down to the countryside and today (All rights reserved).

years has taken a keen personal interest in the history of the Cultural Revolution. This non-professional concern has allowed him to broach topics completely outside the scope of official research, such as the heterodox ideas to be found among the youth or the role of "social contradictions" during the Cultural Revolution.

The works dealing with this period fall into three major categories. The first deals with the phase that could indeed be called "revolutionary," during which the population, even if it was being manipulated, participated in overthrowing the established leaders. Here the Red Guards played a major role, which was brought to an end with their disbandment and the restoration of the political order by the Ninth Party Congress in April 1969. The works of this first kind focus on the period known as the "Three Years of the Cultural Revolution" (san nian wenge). Officially sanctioned research, by contrast, usually focuses on the inner-Party power struggle that broke out violently in 1966 and only ended (albeit provisionally) with the death of Mao, followed by the arrest of the Gang of Four. Works of this kind therefore deal with the "10 Years of the Cultural Revolution" (shi nian wenge). Another important category of works deals with the movement to send the educated youth to the countryside (shangshan xiaxiang yundong). ${ }^{(12)}$ Partly as a means of getting rid of the Red Guards, the movement was launched in 1968 and lasted until 1980. It was unquestionably a part of the history of the Cultural Revolution, being both its early product and its later prolongation.

This movement left a deep mark on a whole generation, and it was the subject of a semi-official interpretation in 1987 in the contribution to the collection entitled An assessment 10 years later cited above. ${ }^{(13)}$ But 10 more years were to pass before the appearance of a real semi-official history in the form of two companion works under the editorship of the former chief of the Central Office for Educated Youth, Gu Hongzhang. ${ }^{(14)}$ Although they are dated 1996, these two works only appeared in 1997, after last minute adjustments to their contents. It was only thanks to the help of Zhang Hua, a research worker at the Research Centre on the History of the Party, that they obtained their final imprimatur. In a Note to the Reader slipped into one of the works, the editors emphasise the orthodox and officially approved nature of their book; their project was first approved by the Ministry of Labour, followed by permits from the Office for the Press and Publications, from the Propaganda Department, and finally from the experts at the Research Centre on the History of the Party. Their very insistence shows that, even for such officially favoured writers, the topic was

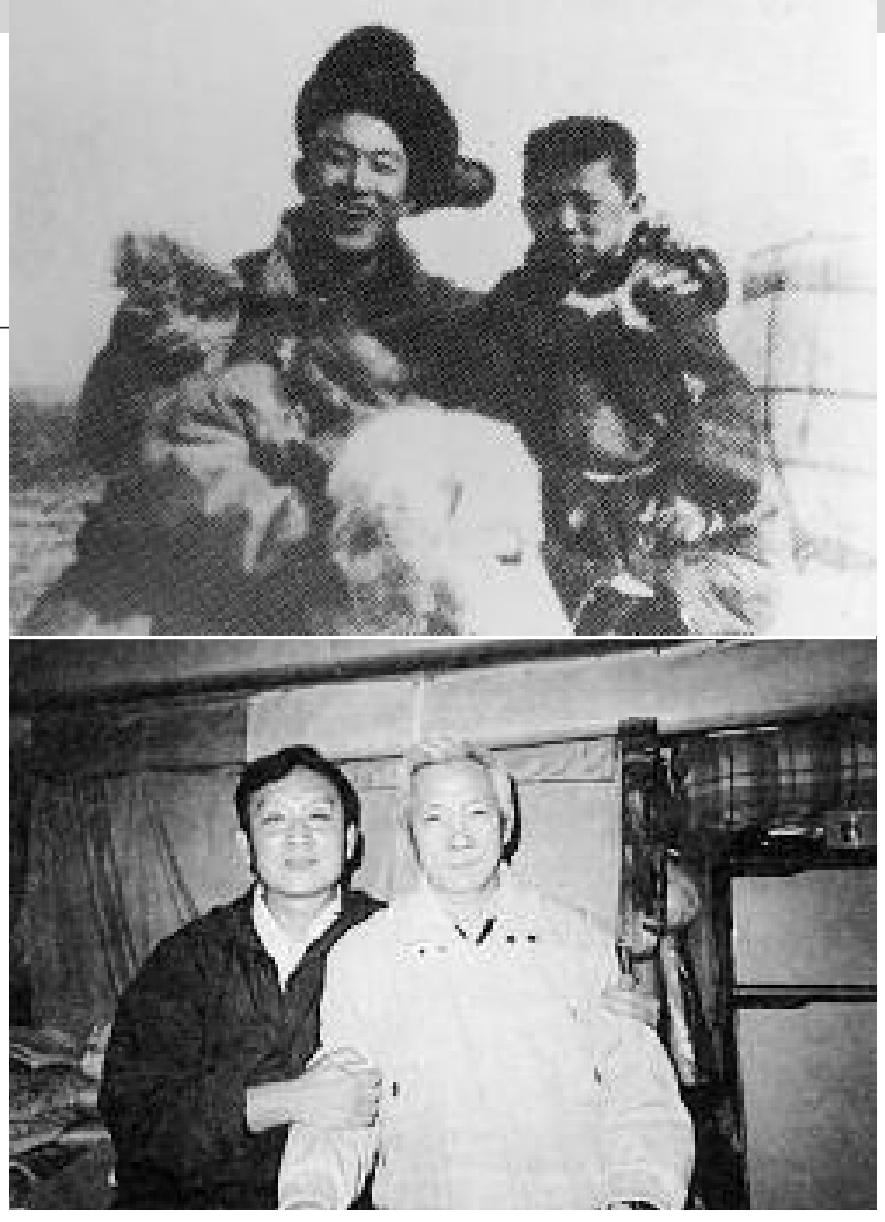

still very sensitive. Shortly afterwards, however, in 1998 (which was the 30th anniversary of the beginning of the movement but was also a relatively liberal year), the authorities went further by not preventing the Academy of Social Sciences from publishing a history of the movement that was not only far more detailed but also less constrained by the official version. Liu Xiaomeng published a high quality academic study of 875 pages on the movement that was launched in 1968, while Ding Yizhuang put out a shorter work on the despatch of the educated youth to the countryside before the Cultural Revolution. ${ }^{(15)}$ These two writers were in a situation comparable to that of Yin Hongbiao in the sense that although they were research workers at the Academy of Social Sciences, their official area of research was the history of the Manchu dynasty. Their historical work

12. On this movement, see T. Bernstein, Up to the Mountains and Down to the Villages The Transfer of Youth from Urban to Rural China, Yale University Press, 1977; T. Scharping, Umsiedlungsprogramme für Chinas Jugend, 1955-1980, Institut für Asienhunde, 1981; M. Bonnin, Génération Perdue: le mouvement d'envoi des jeunes instruits à la campagne en Chine, 1968-1980, Editions de l'Ecole des Hautes Etudes en Sciences sociales, 2004.

13. Zhang Hua, "Shilun 'wenhua da geming' zhong zhishi qingnian shangshan xiaxiang yundong" (A discussion of the movement to send educated youth to the countryside and the mountains during the 'Great Cultural Revolution'), in Tan Zongji et al., op. cit., pp. 141155.

14. Gu Hongzhang, Hu Mengzhou et al., Zhongguo zhishi qingnian shangshan xiaxiang shimo ( $A$ history of the movement to send the educated youth of China to the countryside), Zhongguo jiancha chubanshe, 1996; Gu Hongzhang, Ma Kesen et al., Zhongguo zhishi qingnian shangshan xiaxiang dashiji (Annals of the movement to send the educated youth of China to the countryside), Zhongguo jiancha chubanshe, 1996.

15. Liu Xiaomeng, Zhongguo zhiqing shi: Dachao (1968-1980), (A history of the educated youth of China: the great tide (1968-1980)), Zhongguo shehui kexue chubanshe, 1998; Ding Yizhuan, Zhongguo zhiqing shi: Chulan (1953-1968), (A history of the educated youth of China: the first waves (1953-1968)), Zhongguo shehui kexue chubanshe, 1998. 
on the xiaxiang movement arose purely from personal interest and was rather disapproved of by their respective Institutes: History in Ding's case, and Modern History in Liu's. Although official tolerance was not unconditional, and the authors had to accept several excisions, the publication of their two books was nonetheless a step forward in building a historical understanding of this period by the Chinese themselves. Unfortunately this step did not herald an abandonment of the restrictions weighing on this field of study, and problems seem to have arisen over simply reprinting these works.

History is always subject to the leadership's assessment of the stability of its own dominance. This assessment is in constant flux, and from this point of view it is clear that Jiang Zemin's replacement by $\mathrm{Hu}$ Jintao as general secretary of the CCP has brought no improvement, but rather the reverse. For example, at the time of the 30th anniversary in 1996, several round table discussions and study days were organised by research institutions, and two journals (Qingnian baokan shijie and Jiaodian) dared to produce dossiers or special issues. Another one, the well known intellectual journal Dongfang, had an important special issue ready for publication in May but was instructed to change the topic. By contrast, for the 40th anniversary in 2006 no conferences or publications were allowed. Only one small round table discussion could be held that year, in complete secrecy, from 24 to 26 March. ${ }^{(16)}$

\section{Safe havens for History: publications overseas, in Taiwan and in Hong Kong}

Given these conditions, it is hardly surprising that many works by mainland Chinese writers have been published abroad, in Taiwan, and especially in Hong Kong. The latter still partly retains the leading role it has always played in the study and knowledge of Chinese affairs, as a colony transformed into a "territory" and then, after 1997, into a Special Administrative Region. Not only is Hong Kong the main centre of publication for critical intellectuals seeking to produce genuine historical work on the Cultural Revolution, but also, in a supreme irony, the only place where it is possible to publish the memoirs of former communist leaders who used to have nothing but contempt for the capitalist colony (in some cases, these are posthumous publications organised by their families). Among the latter works are to be found the memoirs of such figures as General Wu Faxian, which contains many insights into the Lin Biao affair, the conservative Maoist ideologue Deng Liqun, the former Beijing leader $\mathrm{Wu}$ De, and the former leader from Shanghai, Xu Jingxian. ${ }^{(17)}$
Some of the intellectuals who have published in Hong Kong, such as $\mathrm{Xu}$ Youyu and Tang Shaojie, still live in China, while others, like Wang Youqin and Song Yongyi, live in exile abroad. It is not possible to list here all the works relating to the Cultural Revolution that have been published in Hong Kong. Among them, a book by Xu Youyu provides a sensitive analysis of the developing outlook of the Red Guards and the educated youth, and he tries to give a comprehensive answer to the question as to who the "rebel" Red Guards were, and what motivated them. ${ }^{(18)}$ Song Yongyi and Sun Dajin give several examples of heterodox thinking that appeared during the Cultural Revolution taken in its broadest sense, ${ }^{(19)}$ and Wang Youqin has published a work based on her own lengthy research, which sets out in detail everything that is known about the circumstances surrounding the deaths of 659 victims of the movement. ${ }^{(20)}$ On the occasion of its 40th anniversary, Liu Guokai published a four-volume collection, including his first work cited above, together with more recent writing such as his "Theory of the People's Cultural Revolution." (21) Other works deal with particularly bloody episodes, such as the 1968 massacres in Guangxi ${ }^{(22)}$ or the affair of the so-called "Inner Mongolian People's Party," ${ }^{23)}$ while still others give historical accounts of the Cultural Revolution in specific institutions, such as Ts-

16. However, it should be noted that one conference was organised by the University of Bohai from 17 to 19 May on "The gathering and managing of historical material concerning the Cultural Revolution." See Xu Youyu, "Zhimian lishi: Zhongguoren dui wenhua da geming de yanjiu" (Facing up to history: Chinese studies dealing with the Cultura Revolution), a paper given at the Ecole des Hautes Etudes en Sciences Sociales, Paris, 2 June 2006.

17. Wu Faxian, Suiyue jiannan - Wu Faxian huivilu (Difficult years - the memoirs of Wu Faxian) (2 vols.), Beixing chubanshe, Hong Kong, 2006; Deng Liqun, Shierge chunqiu (1975-1987) (Twelve Springs and Autumns - 1975-1987), Bozhi chubanshe, Hong Kong, undated; Wu De, Shinian fengyu jishi - wo zai Beijing gongzuo de yixie jingli (A chronicle of 10 troubled years - some experiences of my time working in Beijing), Dangdai Zhongguo chubanshe, Hong Kong, 2004; Xu Jingxian, Shinian yi meng - Qian Shanghai shiwei shuji Xu Jingxian wenge huiyilu (A 10-year dream - memoirs of the Cultural Revolution by the former Party secretary on the Shanghai city council, Ma Jingxian), Shidai guoji chuban youxian gongsi, Hong Kong, 2004.

18. Xu Youyu, Xingxingsese de zaofan - Hongweibing jingshen suzhi de xingcheng ji yanbian (Every kind of rebellion - Formation and development of the Red Guard mentality), Zhongwen daxue chubanshe, Hong Kong, 1999.

19. Song Yongyi \& Sun Dajin, Wenhua da geming he tade yiduan sichao (Heterodox Thoughts during the Cultural Revolution), Tianyuan shuwu, Hong Kong, 1997. Song has also written a work about the massacres and compiled a CD of Cultural Revolution material, both of which are published in Hong Kong (see the article by Wang Youqin in this issue).

20. See her article in this issue.

21. Liu Guokai, Renmin wenge congshu si juan (A collection of works on the People's Cultural Revolution, in four volumes), Boda chubanshe, Hong Kong, 2006.

22. Xiao Ming, Guangxi menge tongshi gouchen (A Painful History: Cultural Revolution in Guangxi Province), Xin shiji chubanshe, Hong Kong, 2006.

23. Gao Shuhua \& Cheng Tiejun, Neimeng wenge fengyu - Yiwei zaofanpai lingxiu de koushushi (Cultural Revolution in Inner Mongolia - Oral History of a Rebel Leader), Mingjing chubanshe, 2007. 
inghua University ${ }^{(24)}$ or the Foreign Ministry. ${ }^{(25)}$ We should also stress the very important role played by the Hong Kong press in the historical debates and reflections upon the $\mathrm{Cul}$ tural Revolution. Independent Hong Kong political journals such as Zhengming, Dongxiang, and Kaifang regularly publish articles on the subject. The academic journal Ershiyi shiji (21st Century) has also played a crucial role, especially with its publication of four special issues for the 30th anniversary in 1996, the articles of which were later published as a book, ${ }^{(26)}$ and again with its publication of additional articles for the 40th anniversary in 2006. ${ }^{(27)}$ Among the Taiwan publications are two noteworthy works by a Tibetan writer, Woeser (Weise), which throw new light on the Cultural Revolution in Tibet. One is a detailed commentary accompanying many photographs left by her father, who was a professional photographer at the time; ${ }^{(28)}$ the other is an oral historical record consisting of 23 personal accounts by people who lived through the Cultural Revolution in Tibet. ${ }^{(29)}$ With regard to the photographic records of the movement, we should also note the collection of the former official photographer Li Zhengsheng, part of which was published in the United States and France in 2003 and includes photographs of the public humiliation of some well known leaders. ${ }^{\left({ }^{30}\right)}$ In the United States a considerable role has been played by the journal Dangdai Zhongguo Yanjiu (Modern China Studies), published in Princeton by some resident Chinese intellectuals with "pro-democracy" backgrounds. Of course, quite apart from these printed publications, the development of the Internet has created new possibilities for spreading current research and analyses of the Cultural Revolution.

The existence of spaces of freedom outside China, or on her margins, has allowed debates between historians to take place. One topic of heated discussion is the idea mentioned already, of "a people's Cultural Revolution." According to this theory, there were "two Cultural Revolutions": the official one, which was a power struggle led by Mao against leaders whom he considered his enemies, and the people's version, which took advantage of the freedoms provisionally granted by Mao to defend their interests and pursue their own goals. The proponents of this theory insist on the importance of the "social contradictions" of the time in shaping both the actions of the Red Guards and the way the events developed, whereas the defenders of the "single $\mathrm{Cul}$ tural Revolution" thesis tend to explain it solely by recourse to the "political contradictions" between Mao and those he accused of "taking the capitalist road." As is frequently the case, those who acknowledge the huge complexity of the
Cultural Revolution are certainly the more convincing. Without denying that the "big chaos" intended by Mao gave certain groups the opportunity to defend their social interests and to begin questioning the ideological basis of the regime (which in the long run has not been without its consequences), these thinkers insist nonetheless that the initiative always remained in Mao's hands, and that the bureaucratic system itself was not fundamentally shaken. Consequently, the "second Cultural Revolution" was largely subordinate to the first. This issue, while not being entirely identical with the choice between "three years" or "10 years" to demarcate the period of the Cultural Revolution, is closely linked to it, since the power struggle was not resolved until 1976, whereas explanations relying on "social contradictions" become far less clear-cut for the period after 1969, when the Red Guards were suppressed and disbanded and the Party was reconstituted at the 9th Congress.

Another contentious subject is that of the "rebel" Red Guards, who were completely demonised by the authorities, but have become "rehabilitated" to a certain extent by defenders of the concept of the "Cultural Revolution by the people." But there are still differences of opinion regarding the socio-political provenance and motives of these rebels. One of the contributions made by Xu Youyu's book cited above is to show that there is no straightforward answer to the question (not all the rebels were malcontents with a bad social background), and that circumstances could vary from region to region. ${ }^{(31)}$

This brief survey of the historical writing on the Cultural Revolution in Chinese would be incomplete without clearly stating that the work of foreign experts on the subject, and

24. Tang Shaojie, Yi ye zhi qiu - Qinghua daxue 1968 nian "bairi da wudou" (An Episode of the Cultural Revolution: the 1968 Hundred-day War at Tsinghua University), The Chinese University Press, Hong Kong, 2003.

25. Ma Jisen, Waijiaobu wenge jishi (The Cultural Revolution in the Foreign Ministry), Zhongwen daxue chubanshe, Hong Kong, 2003.

26. Liu Qingfeng (ed.), Wenhua da geming: Shishi yu yanjiu (The Cultural Revolution: Facts and Analysis), Zhongwen daxue chubanshe, Hong Kong, 1996.

27. Hong Kong's Chinese University Press which publishes Ershiyi shiji, is also responsible for a large part of the works dealing with the Cultural Revolution. For many years now it has played a leading role in research on the topic.

28. He was also a senior PLA officer, and was thus able to take sensitive photographs by virtue of his position (Editor's note).

29. Zeren Duoji \& Weise, Shajie (Forbidden Memory: Tibet During the Cultural Revolution), Dakuai wenhua chuban gufen youxian gongsi, Taipei, 2006; Weise, Xizang jiyi (Tibetan memoirs), Dakuai chuban gufen youxian gongsi, Taipei, 2006.

30. Li Zhengsheng, Le petit livre rouge d'un photographe chinois — Li Zhengsheng et la Révolution culturelle, Phaidon, Paris, 2003.

31. See Xu Youyu, op. cit. See also He Shu's criticism of the book by Zhou Lunzuo entitled Wenge zaofanpai zhenxiang (The true face of the rebels of the Cultural Revolution), at the following website: http://www.tecn.cn/data/detail.php?id=11968. 
the debates between them, have played and continue to play an important role in this area, and have considerable influence on their colleagues in China or of Chinese origin. After all, for many years the only serious studies of the subject were by foreigners. But times have changed, and there is good reason to think that the future of such historical studies lies in the collaboration between Chinese and foreign scholars, with the former playing an increasingly leading role.

\section{Remembering and forgetting}

The work by unofficial Chinese historians is not only aimed at producing a solid and well reasoned account of the facts of the past, but also at preserving the population's memory of them, and ensuring their transmission to future generations. As we have seen, even an official writer such as Wang Nianyi claims this purpose, which is even more pronounced among the unofficial writers. However, it comes up against what can only be called a "wilful forgetfulness" on the part of the authorities.

\section{The official attitude: the missed opportunities of 2006}

As we have seen, the Chinese authorities have been extremely reluctant to authorise even official or semi-official publications, and in the latter cases permission has sometimes been quickly suspended. In fact, publishing houses have been warned, just like newspapers and journals (let alone TV and radio broadcasters), that the Cultural Revolution is a "forbidden area" or at least a sensitive one liable to severe restrictions. Unsurprisingly, this prohibition does not appear to have faded with the passage of time, as demonstrated by the official attitude in 2006, 40 years after the movement was launched and 30 years after it officially ended.

The Cultural Revolution overturned the lives of many Chinese people still alive today, including high ranking officials, intellectuals, and artists. All of these are the kind of people who typically reflect on history and shape the collective memory, and it would seem that the times have changed sufficiently to allow them the necessary historical distance to do so. The era when Mao attempted to reinvigorate the Communist utopia and "keep politics in control" seems very distant from China's present participation in the WTO and the processes of capitalist globalisation. Is it not possible now for the Maoist past, including the Cultural Revolution, to be transformed into History, that is, into a genuine and reasoned historical account which would allow the healing of wounds to begin, and the facts to be handed on to the younger generations?

It has to be said that this is not the view taken by the leading officials in China, who are still acutely embarrassed by the history of the regime that produced them. In response to the 40th anniversary of the launching of the Cultural Revolution (generally dated back to the Circular of May 16th 1966), not only did the authorities remain completely silent, but they also issued strict instructions that it was not to be mentioned in any of the media. There was even a prohibition on any academic activities around the subject, so that the major Chinese language conference to commemorate the event was held in New York from 12 to 14 May 2006, having been organised by researchers from China working in the United States. About a dozen historians living in China were invited but were not allowed to attend. However some of them, as we have seen, managed to organise a clandestine conference in Beijing, and a summary of the proceedings was read out in New York. The proceedings of the American conference, whose title in English was "Historical Truth and Collective Memory: International Conference for the 40th Anniversary of the Cultural Revolution," were published in Chinese in Hong Kong. ${ }^{(32)}$

Neither was there a commemoration of the arrest on $6 \mathrm{Oc}$ tober 1976 of Mao's close associates (now known as the Gang of Four), although it was widely supported by the population at the time. Clearly this absence is explained by the Chinese government's wish to preserve a positive image of Mao himself. The 30th anniversary of the Great Leader's death on 9 September was not accompanied by any analyses or reflections in the press, but an evening of spectacles in his honour was organised and shown on television. In ef fect, while the historical reality of Maoism (especially its darker aspects) remains taboo, the myth of the founding father is raised to the skies.

This desire to sustain a historical myth, together with the intention to maintain a political monopoly on historical interpretation, is incompatible with the development of a critical history. That is clearly demonstrated by the "Bingdian affair." This widely acclaimed supplement to the China Youth News was temporarily closed by the authorities in early 2006, and its chief editor was sacked. His crime was having published a long article in which a historian, Yuan Weishi,

32. Song Yongyi (ed.), Wenhua da geming: lishi zhenxiang he jiti jiyi (The Cultural Revolution: Historical Truth \& Collective Memory), (2 vols.), Tianyuan Shuwu, Hong Kong, 2007. 
The cover of Xu Youyu's book 1966: Memories of our generation (All rights reserved).
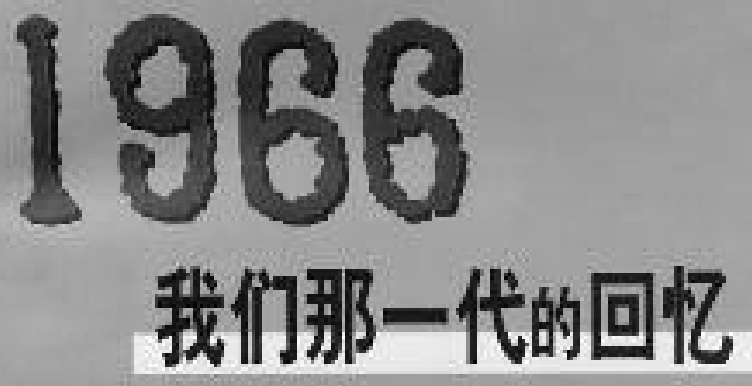

criticised the one-sided and twisted version of history in Chinese textbooks, supporting his view with precise examples. Official anger was no doubt exacerbated by his explicit references to the Chinese government's protests at the time against the Japanese whitewash in some of their textbook versions of the invasion of China by the Japanese Imperial army. ${ }^{(33)}$

\section{Popular memory versus official amnesia}

Yuan Weishi's criticisms are shared by a number of historians and intellectuals who are alarmed by the systematic and ruthless efficiency of the Chinese government's control over history. This is particularly true in the case of the generation of the Cultural Revolution and the "lost generation" ${ }^{(34)}$ of former Red Guards and "educated youth" sent down to the countryside. These people are now frightened by the younger generation's complete ignorance or, even worse, their distorted understanding, of this crucial period in the recent history of China. One distinguishing feature of members of the "lost generation" is that they continue to suffer from the effects of being denied the right to a proper education. Only a small proportion of them who managed to pass the university entrance exams in 1977 and 1978 were able to benefit from a higher education. When the authorities reintroduced those exams in 1977, they provisionally allowed the age of the candidates to be raised, in order to give some of that generation a last chance at access to a genuine higher education. This privileged position, combined with a strong sense of belonging to a deprived generation, made a number of them feel "a duty to remember." One of them is $\mathrm{Xu}$ Youyu, who notes with great concern that younger intellectuals are being led into wishing for a return of the Cultural Revolution through their misunderstanding of its history. In his view, it is high time to "face up to history" (the title of one of his works) ${ }^{(35)}$ and to "rescue the history of the Cultural Revolution" (the title of a lecture that he gave in Paris in June 2006). Like other intellectuals of his generation, $\mathrm{Xu}$ relies on oral history to compensate for the difficulty of gaining access to historical documents, which are jealously guarded by the authorities. The aim of a large number of researchers and editors is to encourage the emergence of a memory of "the people" (mingjian) to stand against official amnesia. Thanks to their efforts, a considerable number of documents, eye-witness accounts, and analyses have been published in Chinese, particularly in Hong Kong, Taiwan, and the United States, but also in the People's Republic itself.

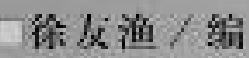

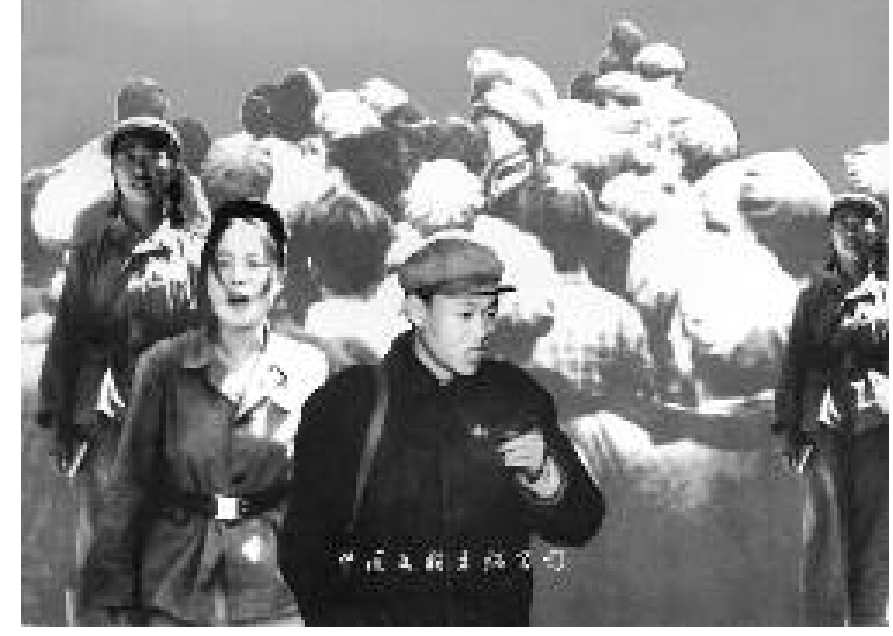

Among the early efforts to revitalise that period and to enable reflection upon the Red Guards' experience, special mention should be made of the film director and experimental documentary maker Wu Wenguang, who is a member of that generation. As early as 1993, he produced a film called 1966: My time in the Red Guards, which combined images from the time with unconventional commentaries from several former Red Guards on every aspect of their experience. ${ }^{(36)}$ One of the eyewitnesses interviewed in the film was $\mathrm{Xu}$ Youyu, who prepared for the 30th anniversary of the Cultural Revolution a work entitled 1966: Memories of our generation, which included several contributions based on personal memories, written by "liberal-minded" intellectuals (that is, spokesmen of the values of freedom). This work was only able to appear in the short period of tolerance in 1998, and was quickly suppressed. ${ }^{(37)}$

One of the favourite means of "rescuing" the memory of that time is to try to build up an oral history. ${ }^{(38)}$ After pub-

33. See the documentation on this affair in Zhengming, no. 3, 2006, pp. 27-39.

34. For a definition of this generation, see Michel Bonnin, op. cit., and his article, "The 'Lost Generation': Its Definition and Role in Today's Chinese Elite Politics," Social Research, vol. 75, no. 1, Spring 2006, pp. 245-274.

35. Xu Youyu, Zhimian lishi (Face up to History), Zhongguo wenlian chubanshe, 2000.

36. Wu Wenguang, 1966: wode hongweibing shidai (1966: My time in the Red Guards), 1993, 3 VCDs. Wu has also published a book in Taiwan about the making of this film: Wu Wenguang, Geming xianchang 1966 - Yibu jilupian de paishe shouji (Revolutionary site 1966 - Notes on the making of a documentary), Shibao wenhua, Taipei, 1994.

37. Xu Youyu (ed.), 1966: women neiyidai de huiyi (1966: memories of our generation), Zhongguo wenlian chuban gongsi, 1998.

38. See, for example, Xing Xiaoqun, "Koushu shi yu 'wenge' yanjiu" (Oral history and the study of the 'Cultural Revolution'), Dangdai Zhongguo yanjiu, Summer 2006, pp. 82-93. 
sorship. ${ }^{(4)}$ Equally noteworthy is the small journal (consisting of one or more newssheets per issue) entitled Wangshi (The Past). Largely the work of Zheng Zhongbing, it is mostly restricted to a small circle of friends and acquaintances. Like Old Photos, it is a source of a lot of reliable, if somewhat fragmentary, information and is of particular interest to the specialist. Some of its documentation deals with the Cultural Revolution. ${ }^{(42)}$

The aim of the historians quoted above is to act in such a way that the people will create "their own history" in the face of official obfuscation. Beyond their concern with the historical record, they are trying to build a collective memory that will be critically aware and free from the ideological stereotypes of the past. Clearly, such an autonomous memory would clash with the authorities' wish to maintain control, for they are in principle suspicious of everything to do with the minjian, i.e. anything unofficial or registered in "the space of the people," to translate it literally. The borderline between the merely unofficial and the actively anti-official is not fixed, as is shown by a collection of 11 works published in 2001-2002 by Workers' Publications (Zhongguo gongren chubanshe) under the overall title of The popular memory of the educated youth of China (Zhongguo zhiqing minjian beiwang wenben). These were all novels based on real historical events, which uncovered some particularly dark sides of the xiaxiang movement. The general editor, Yue Jianyi, explains in his introduction to the series that he wished to contribute towards a genuine memory of the movement by fighting against the idealised descriptions of those tragic times. This approach was a great success from the commercial point of view, and Workers' Publications enjoyed very satisfactory sales. But the Propaganda Department was far less satisfied; the series was banned, the general editor was demoted, and the managing director was summoned by the authorities. He was not only criticised for the negative content of the novels, but also for the series' title. The official from the Propaganda Department even asked "Minjian, why minjian? Does that mean it's against the government?" Nonetheless, the novels were published and a large number of copies were sold. ${ }^{(4)}$

Of course, the memory of being sent down to the countryside did not wait until recently in order to find some kind of expression. By the late 1970s it was already finding an outlet in literary form (to which I will return), and also found an outlet in collectively published personal memoirs. As time passed, these collections were more and more frequently accompanied by photographs, and sometimes even consisted almost entirely of the latter. Some collections were put out by well known publishers and were aimed at the general public, while others were simply exercises in collective memory by limited groups of former educated youth sent to the same rural area. In such cases they often appeared simply under an author's name, without the slightest mention of where they were published or printed. Among the first category of collections intended for the general public, one can feel a great restraint in both the choice of texts and the ideas they express. But in recent years, despite the tightened controls over publishing, the former educated youth, who are now in their fifties or even their sixties, have both more selfconfidence and greater financial means for publishing these collections. They also feel a more urgent need to bear witness to their experiences before advancing age deprives them of the means of doing so. Their desire to hand down these memories to their own children is an additional spur. As a result, certain "sensitive" subjects related to the campaign to send them down to the countryside are no longer avoided. The Sichuanese, who are often quite rebellious, seem to be the boldest in this area. In addition to an interesting book of memoirs by zhiqing sent into the province's mountain region before the Cultural Revolution, ${ }^{(4)}$ another work, by former educated youth from Chongqing and Chengdu who were sent to Yunnan, draws attention to a largely tabooed subject: the zhiqing revolt in the late 1970s. ${ }^{(4)}$ The contributors are all former participants in that great movement of strikes and hunger strikes, which played a major role in bringing an official end to the policy of sending people to the countryside. Public sales of this extremely interesting collection were swiftly forbidden, but it continues to circulate among friends and acquaintances.

Despite these brave "rescue" attempts, the production of a genuine history and memory of the Cultural Revolution is far from easy. Compared with the situation of the Jews after the Second World War, or of the victims of the Soviet sys-

41. One of the reasons for its continuing survival is that, like Oral History, it does not present itself as a journal but as a series of separate publications. Since it is extremely difficult to get permission to publish a journal, it is a better tactic to publish books because ISBN numbered publications are less strictly controlled.

42. Wangshi is also the name of a journal-cum-book series very similar to Old Photographs, which has published several "issues" containing photos and articles on specific periods of the history of the PRC. It is published by Baihuazhou wenyi chubanshe.

43. According to an interview with Yue Jianyi on 5 August 2005.

44. Deng Peng (ed.), Hunxi Dabashan - Chongqing 1964-1965 lao zhiqing huiyilu (Our soul is attached to Dabashan - Memories of former educated youth from Chonqing who left in 1964-1965) (2 vols.), publisher unknown, 2005.

45. Qu Bo \& Luo Xiaowen (eds.), Jufeng guaguo yaredai yulin - Yunnan guoying nongchang zhiqing huiyilu (A hurricane swept over the subtropical forest $-A$ collection of memories by educated youth from the State farms in Yunnan), Zhongguo guoji sheyejia chubanshe, 2006. 
tem after the collapse of the Soviet Union, that of the Chinese intellectuals is more difficult, since most of the archives are not accessible, and even some of the known facts cannot be publicised, because of the political risks. Moreover, certain historical judgements cannot be made in public, and historical research in the field is subject to many restrictions. It is therefore impossible at this point to imagine an organisation like Memorial, which was set up in 1988 in the USSR thanks to Gorbachev's glasnost policy.

There is room for expression, as we have seen, in Hong Kong, Taiwan, and other places overseas, but customs controls prevent outside publications from reaching a wide mainland readership. That is why for several years the Internet has played an important role in disseminating articles commemorating the Cultural Revolution and the campaign to send youth to the countryside. However, the Internet is far from being free of ideological controls. The most outspoken articles are only to be found on foreign websites, and some are inaccessible in China because of official blockage. Even so, some do manage to get past the censorship, thanks to special software, and above all thanks to the fact that Chinese websites enjoy greater tolerance (or a greater difficulty in imposing absolute control) than printed publications. The Internet consequently provides the principal outlet for memories of the Cultural Revolution, and the extremely "reactive" nature of that medium allows debates to take place, even if there is never complete protection against interference by the authorities.

Another technical advance that favours the expression of non-authorised memories has been the development of the digital camera. It is now possible to produce films without expensive heavy equipment, and film-makers have been able to take advantage of this advance to produce documentaries completely outside the official distribution networks. That is how $\mathrm{Hu}$ Jie has produced two films that are outstanding both for their technical and artistic qualities and for their contribution to the history and collective memory of the Cultural Revolution. The first of these, Seeking the Soul of Lin Zhao, tells the story of an exceptional woman who courageously defended her moral and political ideals from 1957 up until her execution during the Cultural Revolution. ${ }^{(4)}$ The second film, Though I am Gone, is dedicated to Bian Zhongyun, the first teacher to be killed by her pupils during the Cultural Revolution. This latter documentary, which is mostly constructed out of photos taken by her husband after her death, and out of a painstaking reconstruction of the circumstances of the time, is a particularly impressive achievement. ${ }^{(4)}$ Although these two films cannot be shown through

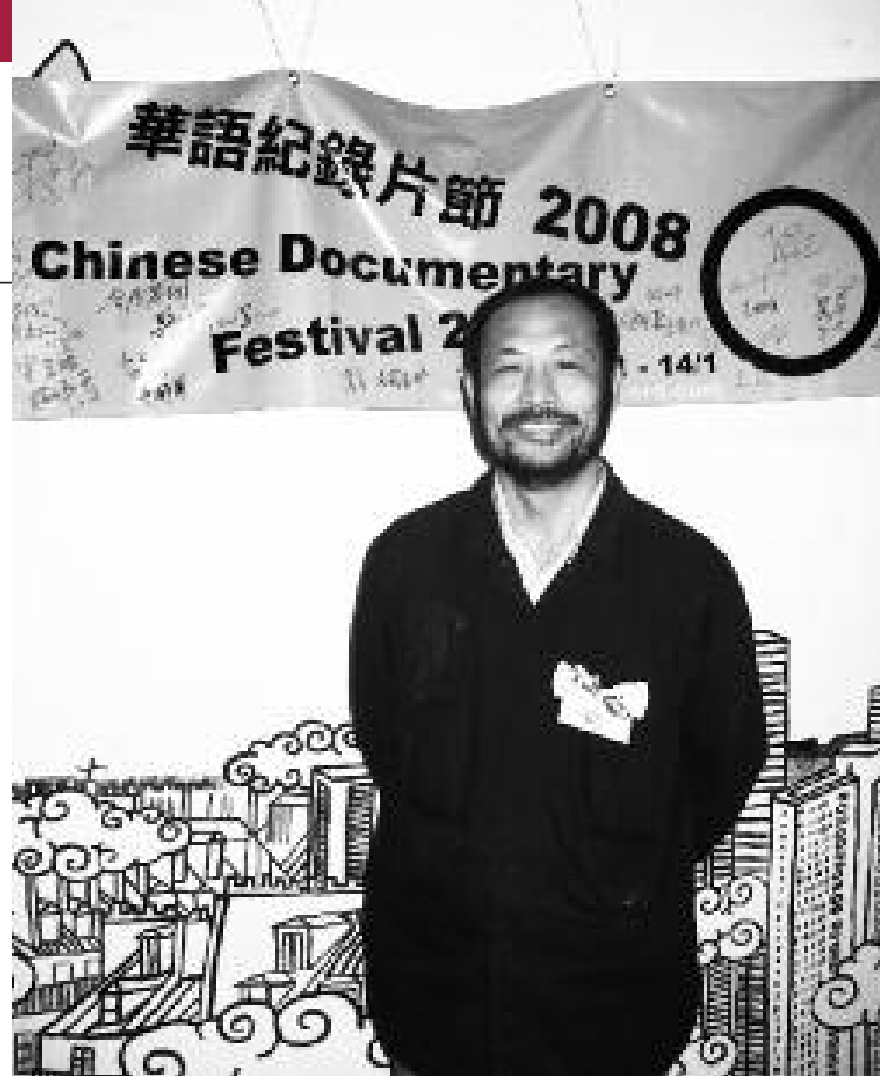

official channels, they have circulate widely as DVDs and are shown in private, or even in certain institutions such as universities and research centres; the second of them is available on YouTube.

\section{The conflict between different memories}

The struggle waged by Chinese intellectuals conscious of their "duty to remember" is not only aimed against official oblivion. It is also a struggle against specific memories that they consider inaccurate or distorted. In fact, as with any important event, the Cultural Revolution has left more than one memory, and the different memories are themselves suffused by two opposing responses, nostalgia and critical distance. Nothing could be more banal and widespread than nostalgia for the days of one's youth, particularly when those days were part of exceptional times that have left strong traces in their wake. Even those intellectuals who are most fiercely critical of the Cultural Revolution and the campaign to send the youth to the countryside tell agreeable or interesting personal anecdotes about those times. But they are opposed to the huge wave of uncritical nostalgia that swept through a large segment of their generation in the 1990s, whether in the form of exhibitions of objects and photographs, the opening of theme restaurants recalling the educated youth sent to this or that region, or the production of films, articles, photo albums, and various knickknacks. They see in all this a culpably complacent acceptance of the prop-

46. Hu Jie, Xunzhao Lin Zhao de linghun (Seeking the Soul of Lin Zhao), 100 minutes, two VCDs, 2004.

47. Hu Jie, Wo sui siqu (Though I am Gone), 67 minutes, one VCD, 2005 
aganda spread about both then and now, particularly in the abuse of the revolutionary icons and songs of the time.

This nostalgia is in fact officially encouraged, and it is certainly no accident that the first big exhibition on the xiaxiang movement was opened with great fanfare in 1990 shortly after the events of June 1989, and moreover in the Beijing History Museum, that is to say, on Tiananmen Square. ${ }^{(48)}$ This was clearly a matter of officially endorsing one memory in order to conceal another more recent and politically dangerous one. Furthermore, the markedly official nature of the exhibition imposed its own orthodox set of interpretations, filtered through the nostalgia evoked by the display of yellowing photographs and old maize stalks.

The variety of different memories is a natural phenomenon. In the late 1970s these found expression in literature, the only realm in which popular memory was allowed an outlet (albeit still under the control of the censorship). Writers with differing sensibilities expressed their personal responses, especially to the rural experience of their generation, since the Red Guards period remained a taboo subject. Two of these writers even produced a form of oral history as early as the 1980s through the publication of collections of interviews. ${ }^{(49)}$ In the 1990s, a large number of publications were collections of memoirs. This period also saw the appearance of works with a historical purpose, along with articles investigating the fate and particular characteristics of that generation, and asking what attitudes it should take now towards its experiences and the times that it lived through.

Heated debates were conducted through various publications, and increasingly on the Internet, over a saying that had become the slogan for those who proclaimed their pride in their past experiences: gingchun wuhui, which could be roughly translated as "I regret nothing of my youth." Two leading ideas are simultaneously expressed in this slogan: on the one hand, it states that the young people of that time lived through a significant period and that they made a contribution to the country at the cost of great personal sacrifice; on the other hand, it claims that they are not responsible for the decisions made at that time, since they were simply forced to participate collectively in movements launched by the authorities. Their critics maintain, on the contrary, that their lost youth cannot fail to cause them regret, given that all the sacrifices demanded from them were in vain, and that they were robbed of their right to an education, manipulated for political reasons that did not concern them, and sacrificed for projects with catastrophic economic and ecological results. ${ }^{(50)}$ But there are still others who think that they should feel not only regret but also remorse, because they were not merely victims. They participated in the victimisation of others, particularly when acting as Red Guards or as collaborators of one kind or another in the political activities of the time. So there has also been a debate as to whether that generation ought to "repent" (chanhui) or not. ${ }^{(51)}$

Clearly there is a political subtext to these debates. Those who take a critical position towards their experiences are also those who want the introduction of political changes to prevent a possible recurrence of such events, and the elimination of the remnants of the system that allowed them to happen. Their opponents are more easily satisfied with official declarations and, to put it bluntly, with official amnesia. There are many complex reasons behind this attitude. Apart from the fact that the population as a whole is not used to criticising and taking control of its own affairs, the present generation has obviously had difficulty coping with the socio-economic disruptions of the last decade, which have increased their inability to adapt to post-Maoist society. The millions of the unemployed dismissed from State enterprises are mainly members of this generation. Their expressions of pride in the past can therefore be seen as a way of reasserting their deeply threatened identity, and as an indispensable consolation for a generation that finds itself sacrificed yet again. Moreover, neither cultural tradition nor the political system encourages public repentance from those who have real reasons for it. Faced with such a painful past, many see silence and forgetting as the only solution, even though there have actually been some cases of Red Guards publicly asking for forgiveness from their former victims.

\section{The Memory Archipelago}

In conclusion, unofficial memory does exist, but as an archipelago whose little islands are threatened by the vast surrounding ocean of official oblivion. If the scattered and localised attempts to construct a social memory on the basis of diverse and contradictory individual memories are to have

48. The catalogue for this exhibition was published the following year as Hun xi hei tudi (Our soul is attached to the black earth), Jiangsu renmin chubanshe, 1991.

49. Feng Jicai, Yibaige ren de shinian (One hundred people's ten years), Jiangsu wenyi chubanshe, 1991; Zhang Xinxin \& Sang Ye, Beijingren (Man from Beijing), Shanghai wenyi chubanshe, 1986.

50. Good examples of this latter point can be found in a collection of articles produced by a journalist from the People's Daily who is a great "rescuer of memory": Li Hui (ed.) Canque de chuang lanban - Lishi zhong de hongweibing (The ruined guide rail - the Red Guards in history), Haitian chubanshe, 1998.

51. A book on this issue was published and subsequently banned: Yu Kaiwei (ed.), Chanhui haishi bu chanhui (To repent or not to repent), Zhongguo gongren chubanshe, 2004. 
any chance of success, what is needed is an uncensored and unbiased public space in China. This would have to be sufficiently stable to allow debate to leave lasting traces, which would then enable them to accumulate and become the basis for reasoning. At present, such a space for discussion, exchange, and transmission to the new generations does not exist, because the regime would not tolerate it. Those who are fighting against the obliteration of the present generation's memory, and who wish to see the emergence of a genuine and detailed history of the Cultural Revolution, are in a minority and have limited resources. Even though the authorities no longer have absolute power to suppress the production of critical histories or the expression of unauthorised memories, it must be recognised that, given the current relationship between the one-party State and society, the possibility of China developing a true historical understanding of the twentieth century depends upon a change of attitude by the authorities. Admittedly, there is no sign of such a change at the moment, but a time could come when it might be seen as necessary, in view of the problems that the current situation is causing the government.

It can happen that the manipulation of History rebounds on those responsible for it. In this instance, the actual effect of the preservation of the myth of Mao, and more specifically the obfuscation of the real history of the Cultural Revolution, has been to inculcate in the population an ideal image of the revolutionary past, which brings unfavourable comparisons with the corruption and inequalities characteristic of today's China. I recently attended an informal meeting of students at Peking University, and I was struck by the extent to which Maoist ideology still has a critical force for them. Being ignorant of the realities of Maoism, they were in a situation not unlike Western students in the 1960s, with their enthusiasm for the Little Red Book.

Since no one can guarantee any major shift of official policy in the future, there remains a heavy burden on the shoulders of the "lost generation," or at least on those who are conscious of their "duty to remember." And it can be said with confidence that some of them will not give up the struggle over memory without a fight. There is a great deal at stake here for the future of China. And it ought also to be a matter of great concern to all of us outside China, or on its margins, who have the means to help in developing a proper knowledge and understanding of that astonishing and tragic period of world history.

\section{- Translated by Jonathan Hall}

